\title{
The Effect of Maternal Education Level, Family Income, and Maternal Working Time to Basic Vaccine Service on o-24 Infants in Kupang Regency, East Nusa Tenggara
}

\author{
Frans Salesman \\ School of Health Polytechnics Citra Husada Mandiri, Kupang, East Nusa Tenggara
}

\begin{abstract}
Background: Vaccine stimulates immune system form to the infants to prevent the disease and death. However, the coverage of complete basic vaccine (IDL) has not reached the target yet in Kupang regency, Nusa Tenggara Timur. The study aims to analyze the factors that effect a completeness status of the effect basic vaccine for infants aged 0-24 months at the Oemasi regency, Kupang, East Nusa Tenggara.

Subject and Method: The study was observational study using cross-sectional approach. The study was conducted at Oemasi community health center, Kupang regency, Nusa Tenggara Timur. The total of the population were 527 infants aged between 0-24 months. The sample were 60 infants by using quota sampling technique. The independent variable were maternal age, education, and working time, family income, and number of family members. The dependent variable was complete basic vaccine status. The data were collected using questionnaire and analyzed by multiple logistic regression.

Result: The maternal education level increased the infants' possibility to get complete basic vaccine and stasticially significant $(\mathrm{OR}=11.47$; CI $95 \%=1.28$ up to $102.63 ; \mathrm{p}=0.029)$. Parents' income increased infants' possibility to get complete basic vaccine, however it was not statistically signicant. Family member $\geq 5$ people and mother's working time $\geq 7$ hours/day decreased infants' possibility to get complete basic vaccine, however it was not statistically significant. Mother's age did not influence the infants getting complete basic vaccine.

Conclusion: mother's education is a factor which has the strongest effect to increase infants' possibility to get complete basic vaccine.
\end{abstract}

Keyword: complete basic vaccine, mothers' education level, family income, family members

\section{Correspondence:}

Frans Salesman. School of Health Polytechnics Citra Husada Mandiri, Kupang, East Nusa Tenggara. Email: franssalesman@gmail.com.

\begin{abstract}
BACKGROUND
Vaccine is an effort to prevent a disease by giving the dangerous microorganism having been vaccined into the body so that it could stimulate immune system in our body toward kinds of antigen for the future. For the benefit, it can keep the immune system for the infants toward the infectious disease, preventing form defect and death, and assisting the infants development optimally (Masbidin, 2016). Idelally, all 5year-old infants must get complete basic
\end{abstract}

vaccine which is like hepatitis $B$ vaccine prevents hepatitis B, diphtheria vaccine, pertussis vaccine, and tetanus prevents heart failure, nerve system, pertussis, epilepsy; polio vaccine prevents polio infection, measles vaccine prevents measles, BSG vaccine prevents tuberculosis, $\mathrm{HiB}$ vaccine prevents meningitis and pneumonia, and rotavirus vaccine prevents diarrhea (Idfadhilah, 2015). However, the complete basic vaccine which has been provided by the health workers is always 
not requested by mothers of 0-24 months infants for various reason.

Health workers find $80 \%$ of research subject asking for HBV vaccine, $79.20 \%$ for TB vaccine, meanwhile vaccine for preventing from influenza is $28.5 \%$ and Varicella is only 40.3\% (Tore et al., 2017). This study concluded that the demand for death prevented vaccive was higher than pain prevented vaccine for the children survival.

Triana (2015) found that knowledge, behavior, and parents' motivation about vaccine is a factor that influence in giving basic vaccine for infants.

Edison et al (2013) stated that there was no significant relationship between mother's knowledge and giving complete basic vaccine to the infants in Parupuk Tabing sub-district of Lubuk Buaya community Health Center. The previous study has not been conducted yet in analyzing the effect of family income and time spent on IDL demand for infants aged o-24 months.

IDL coverage has not met the target yet in 2016 (Widiyani, 2016). The IDL percentage in the end of 2016 is $82.10 \%$ out of IDL target which is $91.50 \%$. That is the same as 3,589,226 new baby born during 2016. The IDL coverage in 2015 was up to 80\% which was higher than the target 70\% or it was the same as 4,139,903 new baby born in 2015. The target of giving IDL treatment in East Nusa Tenggara in 2016 reaches $35,38 \%$, as a regency in East Nusa Tenggara, Kupang reaches 27.30\% (BPS NTT, 2016). Low level of IDL coverage is caused by various things, such as poverty, and working time from infants mother aged o-24 months.

Poverty in the East Nusa Tenggara province placed the third rank of national rank as big as $22.58 \%$ whicj is equivalent 1.160.530 soul. A poor society lived in the poverty rate of Rp.307.224 with the poverty rate $(\mathrm{P} 1)$ in $3.25 \%$ and severity poverty rate $\left(\mathrm{P}_{2}\right)$ in $0.79 \%$. Kupang is one of regencies in East Nusa Tenggara with poverty rate $(\mathrm{P} 1)$ in $3.48 \%$ and severity poverty $\left(\mathrm{P}_{2}\right)$ in $0.89 \%$. Poor society is easy to get various infection and degenerative disease. Prevalance disease of Kupang regency is reported that upper respiratory tract infection is as many as $55.05 \%$, muscle tissue issues is $10.83 \%$, myalgia is $6.95 \%$, alergic is $5.33 \%$, infection is $4.67 \%$, diarrhea is $3.58 \%$,

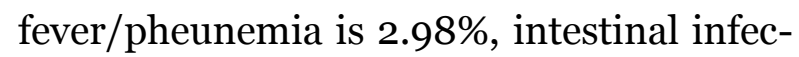
tions is $3.18 \%$, and others is $7.43 \%$ infeksi usus $3.18 \%$, dan lain-lain $7.43 \%$ (NTT Public health Office, 2016).

This study aims to analyze the factors which affect the complete basic vaccine status for the infants aged 0-24 months at Oemasi puskesmas, Kupang regency, East Nusa Tenggara.

\section{SUBJECTS AND METHOD \\ 1. Study Design}

The study was observational study using cross-sectional approaching. It was conducted at Oemasi puskesmas, Kupang regency, East Nusa Tenggara. The population in Kupang regency was 527 infants aged 0-24 months. 60 infants were chosen as the sample by applying quota sampling.

\section{Study Variable}

Independent variable was maternal age, family income, mother working time, and number of family member. Dependent variable was comple basic vaccine status.

\section{Operational Definition}

Family income is an income received by households' head as well as from the family member income (Media BPR, 2016). Ordinal measurement scale. Family income $\leq$ poverty rate $=0$, family income $>$ poverty rate $=1$. Poverty rate determination in East Nusa Tenggara is Rp.307.224 per-capita per month (BPS NTT, 2016). 
Working time is allocated time for a mother who has 0-24 months infants to do a series of activities inside or outside households in an hour (NTT Public Health Office, 2016). Working time $<7$ hours per day $=0$ and working time $\geq 7$ hours per hour $=1$.

Complete basic vaccine usage is a number of vaccine (antigen) such as hepatitis $\mathrm{B}$ vaccine, dhifteri, pertussis, and tetanus; pholio, BCG, and HiB. The vaccine is a must to be given to infants aged $0-24$ months. Ordinal measurement scale. It is incomplete if it is <4 kinds of vaccine (antigen) $=0$, It is complete if it is $\geq 4$ kinds of vaccine $($ antigen $)=1$.
Permission Letter from the head of STIKes Citra Husada Mandiri Kupang Nomor 074/948/DPM-PTSPV/ 2017. The duration the study was june $1^{\text {st }}$ to july $1^{\text {st }}$ 2017.

\section{Data Analysis}

The data analysis was double logistic regression analysis.

\section{RESULTS}

\section{Study Subject Characteristic}

The study subject characteristic was such as maternal age, education level, mother's working time, family income, and number of family member.

\section{Table 1. Univariat Analysis Result}

\begin{tabular}{llll}
\hline \multicolumn{1}{c}{ Variable } & n & & $\mathbf{\%}$ \\
\hline Complete basic vaccine & 20 & 33.3 & \\
Maternal age $\geq 30$ years & 34 & 56.7 & \\
Maternal education $\geq$ SMA & 43 & 71.7 & \\
Family income $\geq$ Rp. 3.000.0oo & 19 & 31.7 & \\
Mother's working time $\geq 7$ hours/day & 22 & 36.7 & \\
Number of family members $\geq 5$ people & 15 & 25 & \\
\hline
\end{tabular}

Complete basic vaccine coverage ( $\geq 4$ antigen) on the sample conducted was $33.3 \%$. Maternal education was mostly

Table 2. Multiple logistic regression analysis result of the factors in influencing complete basic vaccine for infants

\begin{tabular}{|c|c|c|c|c|}
\hline \multirow{2}{*}{ Independent Variable } & \multirow{2}{*}{$\mathbf{O R}$} & \multicolumn{2}{|c|}{$95 \%$ CI } & \multirow[b]{2}{*}{$\mathbf{p}$} \\
\hline & & Lower limit & Upper limit & \\
\hline Maternal age $\geq 30$ years & 1.05 & 0.30 & 3.68 & 0.941 \\
\hline Family member $\geq 5$ people & 0.22 & 0.04 & 1.39 & 0.108 \\
\hline Maternal education $\geq$ senior high school & 11.47 & 1.28 & 102.63 & 0.029 \\
\hline Family income $\geq \mathrm{Rp} 3.000 .000$ & 2.88 & 0.37 & 11.57 & 0.135 \\
\hline Mother's working time $\geq 7$ hours/ day & 0.83 & 0.19 & 3.61 & 0.800 \\
\hline
\end{tabular}

Table 2 showed that mother's education increased the infants' possibility to get complete basic vaccine, and it is statistically significant. The education mother $\geq$ SMA which had the possibility to get complete basic vaccine was 11 times higher than mother's education $<$ SMA (OR= 11.47; CI $95 \%=1.28$ up to $102.63 ; \mathrm{p}=0.029)$. $\geq$ senior high school (71.7\%). Family income was mostly <Rp 3.000.000 (68.3\%). 
complete basic vaccine, however it was not statistically significant. The mother's age did not effect the possibility of the infants getting complete basic vaccine.

\section{DISCUSSION \\ 1. The effect of mothers' education level to complete basic vaccine treatment}

Highly maternal education level increses the infants possibility to get complete basic vaccine. It makes the mother easily to get and receive the information about the benefit of complete basic vaccine treatment.

The complete vaccine protects the children from the plague which is like disability and death. Parents are expected to fulfill their children's vaccine so that all the Indonesian children are protected from the disease through the vaccine. Vaccine protects the children from some diseases such as disability or even death. For the further, vaccine does not need an expensive cost, but the children will get free cost at posyandu instead. However, it was found that hepatitis B vaccine and $\mathrm{HiB}$ Vaccine must be done at Puskesmas because it neesds storage which needs special treatment and also it is a susceptible biological preparation toward the environmental temperature changing Every cold phase, vaccine transportation is done at $\mathrm{O}^{\circ} \mathrm{C}$ to $8^{\circ} \mathrm{C}$. Polio vaccine could be melted and freezed without causing potential vaccine. DPT, DT, dT, hepatitis-B and Hib Vaccine can be broken at $\mathrm{O}^{\circ}$ (hepatitis-B vaccine can be broken at temperature around $-0.5^{\circ} \mathrm{C}$ ) (Ministry of Helath RI, 2009).

2. The effect of family income to complete basic vaccine treatment

Family income increases the infants' possibility to get complete basic vaccine. High income simplify the mother to pay transportation cost to get to vaccine service.
The puskesmas location is far from the settlers so it takes around 3-4 hours for mothers to take their children aged 0-24 months to the puskesmas. The mothers take the public transportation or rented vehicle paid from the family income to go to puskesmas. This circumstance supports the infleunce of family income to complete basic vaccine demand.

\section{The effect of family income to complete basic vaccine treatment}

Either The family member $\geq 5$ people or mother's working time $\geq 7$ hours/day increases infants' possibility to get complete basic vaccine.

A number of family member causes mother to pay less attention to each of family member necessity. The mother might forget the children's vaccine schedule.

Another condition of vaccine treatment at posyandu on weekdays is mothers do not use it well because their daily activity like going to field and also shepherding and those are as their income . This situation explains the more the working time is the lower the complete basic vaccine demanding is. The same thing happens in Olilit Baru village, Maluku Tenggara Barat regency which is there is a correlation between mother's occupation and Complete vaccine (Yanuby, 2013).

According to the result, it can be concluded that mother's education, family income, working time, and family member influence to complete basic vaccine to the infants. Mothers' age do not influence the infants' complete basic vaccine.

\section{ACKNOWLEDGEMENT}

This study is dedicate to the head of School of Health Citra Husada Mandiri, Kupang, Head of Health Department of Kupang regency, Head of Oemasi community health center, Nekamase sub-district, Kupang, and 
Journal of Health Policy and Management (2017), 2(2): 112-116

https://doi.org/10.26911/thejhpm.2017.02.02.02

all the supporting team who has given the ideas in finishing this study.

\begin{tabular}{cc}
\hline \multicolumn{3}{c}{ REFERENCES } \\
\hline Badan Pusat Statistik NTT (2016). & Nusa \\
Tenggara Timur Dalam Angka 2016. \\
Badan Pusat Statistik Provinsi Nusa \\
Tenggara Timur. 2016. Hal.191-287. \\
Dinas Kesehatan NTT (2016). Profil
\end{tabular}

Kesehatan Provinsi Nusa Tenggara Timur 2016. Dinas Kesehatan NTT, 2016. Hal. 198.

Edison, Darwin E, Dewi PA (2013). Hubungan Tingkat Pengetahuan Ibu dengan Pemberian Imunisasi Dasar Lengkap pada Bayi di Kelurahan Parupuk Tabing Wilayah Kerja Puskesmas Lubuk Buaya Kota Padang Tahun 2013. Diakses dari http.portalgaruda.org/article.php?...Hubungan\% 2oTingkat\%20Pengetahuan\%2...

Kementerian Kesehatan RI (2012). Lindungi Ibu dan Bayi Dengan Imunisasi. Diakses dari www.depkes.go.id/pdf.php?id=15010200001 pada 01 September 2017.

Kementerian Kesehatan RI (2009). Pedoman Pengelolaan Vaksin. Katalog. 615. IND-P. Perpustakaan Kementerian Kesehatan RI. Jakarta.

Kusumastuti AN (2012). Pengaruh Faktor Pendapatan, Umur, Jumlah Tanggungan Keluarga, Pendapatan Suami, Dan Jarak Tempuh Ke Tempat Kerja Terhadap Curahan Waktu Kerja Pedagang Sayur Wanita Di Purwodadi. Skripsi. Diakses dari eprints.undip.ac.id/37237/1/KUSUMASTUTI.pdf pada 01 September 2017.

Masbidin (2016). Lima Imunisasi Dasar Lengkap Terbaru Berserta Jadwal
Pemberiannya. Diakses dari https://masbidin.net/imunisasi-dasarlengkap pada 06 Agustus 2017.

Media BPR (2016). Kamus Bisnis dan Bank. Pendapatan Rumah Tangga. Diunduh tanggal 10 Agustus 2017. Diakses dari www.mediabpr.com.kamus-bisnisbank/pendapatan rumah tangga.aspx

Notoadmodjo S (2012). Promosi Kesehatan dan Perilaku Kesehatan. Jakarta: Penerbit Rineka Cipta.

Raharjo S (2017). Makna Koefisien Determinasi ( $\mathrm{R}$ Square) Dalam Analisis Regresi Linier.

Tegar R, Hakim (2012). Curahan Kerja. Diakses dari tegarhakim.blogspot.com/2012/04/curahan-kerja.html pada 10 Agustus 2017.

Tore LG, Scalingi S, Gurato V, et al (2017). Knowledge, Attitude and Behaviours towards Recommended Vaccinations among Healthcare Workers. Journal Health Care. 5(1). ISSN: 2227-9032).

Triana V (2015). Faktor-Faktor Yang Berhubungan Dengan Pemberian Imunisasi Dasar Lengkap pada Bayi Tahun 2015. Diakses dari htp://jurnal.fm.unand.ac.id/index.php/jkma; pada 19 Agustus 2017.

Widiyani R (2016). Target Imunisasi Dasar Tidak Tercapai. Diakses dari www.harnas.co/2016/12/31/target-imunisasi-dasar-belum-tercapai pada o6 Agustus 2017.

Yanuby R (2013). Hubungan Status Pekerja Ibu Dengan Kelengkapan Imunisasi Di Desa Olilit Baru Kabupaten Maluku Barat. Diakses dari https://ejournal.unsrat.ac.id/index.php/jkp/ article/view/3185/2727 pada 01 September 2017. 